\title{
Pluriform Motivation as Moderation of Budget Participation Relationship towards Managerial Performance (Empirical Study on Manufacturing Industry in Indonesia)
}

\author{
Widi Hariyanti $^{1}$, Finisha Mahaestri Noor ${ }^{1}$, Adenanthera L. Dewa ${ }^{2, *}$ \\ ${ }^{1}$ Faculty of Economics, Setia Budi University, Surakarta, Indonesia \\ ${ }^{2}$ Faculty of Economics and Business, Universitas Maritim AMNI, Semarang, Indonesia
}

Received September 14, 2020; Revised November 5, 2020; Accepted November 29, 2020

\section{Cite This Paper in the following Citation Styles}

(a): [1] Widi Hariyanti, Finisha Mahaestri Noor, Adenanthera L. Dewa, "Pluriform Motivation as Moderation of Budget Participation Relationship towards Managerial Performance (Empirical Study on Manufacturing Industry in Indonesia)," Universal Journal of Accounting and Finance, Vol. 8, No. 4, pp. 131 - 139, 2020. DOI: 10.13189/ujaf.2020.080405.

(b): Widi Hariyanti, Finisha Mahaestri Noor, Adenanthera L. Dewa (2020). Pluriform Motivation as Moderation of Budget Participation Relationship towards Managerial Performance (Empirical Study on Manufacturing Industry in Indonesia). Universal Journal of Accounting and Finance, 8(4), 131 - 139. DOI: 10.13189/ujaf.2020.080405.

Copyright $\bigcirc 2020$ by authors, all rights reserved. Authors agree that this article remains permanently open access under the terms of the Creative Commons Attribution License 4.0 International License

\begin{abstract}
Background: Systematic planning and participation will determine the quality of organizational performance. As one of the most important aspects of business planning is budgeting. However, in many cases, budgeting does not only require systematic planning, but also requires high motivation from organizational members If so far, motivation is mostly understood singly, this study analyzed the pluriform motivation in budget planning and managerial performance. Purpose: This research was conducted to examine the effect of budget participation on managerial performance with pluriform motivation as moderating variable. Methodology: This research was conducted by using the unit analysis with the sample of manufacturing company managers in Indonesia. The sampling technique used is the purposive method. Principal results: The result showed that there is a positive influence and significant effect of budget participation on managerial performance. The findings also showed a significant effect of pluriform motivation as moderating on the relationship between budget participation in managerial performance. Major conclusions: In general, the main findings of this study underline the importance of a more in-depth analysis of pluriform motivation in budget planning and management performance. Contributions to the field: This study combines human resource studies and behavioral
\end{abstract}

accounting by investigating employees' participation and motivation and managerial performance in budget planning. Important aspects of the study: This study originally offers the idea that motivation in behavioral accounting and human resources needs to be seen in its plural form. The positive and significant influence of pluriform motivation justifies the importance of this idea in future studies.

Keywords Pluriform Motivation, Budget Participation, Managerial Performance

\section{Introduction}

The theory of motivation generally stated that individual members of the organization will be motivated to achieve performance if there is an assessment of performance in the organization. Deci \& Ryan [1] in the theory of self-determination explained that motivation is divided into three types of motivation, including intrinsic motivation, extrinsic motivation autonomy and controlled extrinsic motivation. Types of motivation are forms of motivation termed as pluriform motivation [2]. Pluriform motivation developed on the basis of self-determination 
theory [2]. Based on the theory of motivation that someone is motivated to do something because there is a desire to meet the psychological needs in him, such as competence, autonomy, and relationships [1].

Several previous studies that examined motivation variable did not distinguish between these motivations. Pluriform motivation will strengthen or weaken the influence of budgetary participation and organizational commitment to managerial performance. Employees will be intrinsically and extrinsically motivated to participate in budgeting if their performance is assessed on a budget. Someone will be motivated to do something because of the psychological need to get something [2]. The research on pluriform motivation variables on managerial performance is still relatively limited, so it needs to be done again to test whether these variables affect managerial performance. As one of the most important aspects of business planning, systematic planning and budget participation will determine the quality of organizational performance. However, in many cases, budgeting does not only require systematic planning, but also requires high motivation from organizational members. Insofar, motivation is mostly understood singly, this study analyzed the pluriform motivation in budget planning and managerial performance.

This research was conducted to examine the effect of budget participation on managerial performance with pluriform motivation as moderating variable. More specifically, this study will examine the effect of pluriform motivation as a moderating variable on the relationship of budgetary participation to managerial performance. The problem of this research is how pluriform motivation as a moderating variable in the relationship of budgetary participation to managerial performance. This research was conducted by using the unit analysis with the sample of manufacturing company managers in Indonesia. The sampling technique used is the purposive method. This study originally offers the idea that motivation in behavioral accounting and human resources needs to be seen in its plural form. The positive and significant influence of pluriform motivation justifies the importance of this idea in future studies.

\section{Theoretical Basis}

Managerial performance is largely defined as the performance of individual members of the organization in managerial activities in the organization. Some of the managerial activities include planning, compiling and implementing tasks and functions that are realized in the budget [2, 3]. Employees as individual members of an organization can improve their performance if they have high organizational commitment. Meyer said that high organizational commitment will increase high performance [3, 4]. Some of the results of previous studies conducted by $[3,4,5]$ show that organizational commitment variable has a significant positive effect on managerial performance. According to Locke \& Latham [6] using motivation theory and goal setting theory that an employee will be motivated to excel if given a task with a new goal [7]. Individual members of the organization will develop strategies that make it possible to achieve company goals.

One company goal can be determined by using the budget as a work plan to achieve goals in the future. The amount of expenditure that must be spent to fund programs and activities planned in the form of a budget also includes how to obtain funds to finance these programs and activities [8]. The budget as a control tool is an important part of management control designed to promote efficiency in the use of resources towards the achievement of the company's strategic objectives [9]. One of the management functions is planning a budget that has benefits because it can improve coordination, reduce uncertainty, and be used for control.

The budget participation process shows how subordinates or executors of the budget are given the opportunity to be involved in preparing the budget and have influence in the budget preparation process. Thus, it is expected that employee involvement in budgeting can improve performance and also provide opportunities for employees to show their work performance [10].

Acceptance of budget targets is related to the breadth of availability of individuals to accept a level of budget targets. Motivation theory becomes a grand theory in research that discusses performance. Achievement of performance by individuals because these individuals are motivated to do something that can improve performance, especially if their performance is evaluated by management. Meanwhile, the theory of self-determination is the development of motivation theory developed by Deci \& Ryan [1] and also becomes a reference theory in this study.

Motivation underlies a person having a commitment to his organization and according to Chong \& Chong [10], managers have a duty in setting budget targets, and they will be more likely to accept and commit to budget goals, compared to managers who are not included in setting budget targets.

A higher level of commitment is seen as a more inclusive concept that is related to one's determination to achieve certain performance. According to Hariyanti \& Purnamasari [3] intrinsic motivation, autonomous and extrinsic controlled extrinsic motivation is thought to influence the behavior of organizational members in improving their performance.

Some of the results of previous studies examining the relationship between independent variables of organizational commitment, pluriform motivation and budgetary participation on managerial performance show conflicting results. Previous research conducted by Hariyanti \& Purnamasari [3] that tested pluriform 
motivation on managerial performance showed insignificant results. Different results are shown in Hariyanti \& Purnamasari's study [3] that intrinsic motivation does not significantly influence performance, whereas autonomous extrinsic motivation and controlled extrinsic motivation have a significant effect on performance. Brownell \& Hirst [12] and Milani [13] find insignificant results of the relationship between budgeting participation and managerial performance. Budget participation cannot improve employee performance. According to research conducted by Owusu et al. [9] showed positive and significant results between budgeting participation on performance. Uniquely, this paper offers a different perspective from previous research, where this paper specifically examines both extrinsic and intrinsic motivation in relation to budgeting performance. More specifically, this study combines human resource studies and behavioral accounting by investigating employee participation and motivation and managerial performance in budget planning

\section{Pluriform Motivation}

Motivation according to Tremblay et al [14] is a set of energetic forces both originating from within and outside the individual self, to initiate the relationship between work-related behaviors in order to establish form, supervision, intensity and continuity. Pluriform motivation according to Hariyanti \& Purnamasari [3] is some forms of motivation namely intrinsic motivation, autonomous extrinsic motivation and controlled extrinsic motivation. Intrinsic motivation is motivation that comes from within an individual. Intrinsic motivation involves someone in carrying out an activity because they find it interesting and gain satisfaction in doing the activities they do [11].

According to Vansteenkiste et al [15] competency needs underlie the formation of intrinsic motivation, where people are involved in various activities to gain experience, demonstrate and apply their competencies. Autonomous extrinsic motivation according to Gagné \& Deci [11] is defined as an action carried out by someone based on what they want that gets encouragement from outside the individual self. Controlled extrinsic motivation is identified as motivation that can be controlled by an individual due to external regulations and their behavior is carried out primarily to meet external demands such as orders from superiors [5].

\section{Budget Participation}

Budget participation is a process in which individuals in it are involved and have an influence on the preparation of budget targets, whose performance will be evaluated, and may be valued on the basis of achieving these budget targets. Milani [13] explains budgetary participation is a reflection of superiors' perspectives on the level of involvement experienced by subordinates in the preparation of the budget and involved in the final budget and the contribution/contribution of his thoughts is needed for the budget. The main function of the budget according to Mardiasmo [16] is as a planning tool, a control tool, a fiscal policy tool, a political tool, a coordination and communication tool, a performance appraisal tool, a motivational tool and a tool for creating public spaces. According to Siegel \& Ramanauskas-Marconi [17] the application of participation in budgeting provides many benefits, among others that participants (people involved in the budgeting process) become ego-involved not just task-involved in their work; participation will increase the sense of togetherness in the group, which consequently will increase the cooperation of group members in implementing the objectives; participation will increase the sense of togetherness in the group, which consequently will increase the cooperation of group members in implementing the objectives; participation can reduce the feeling of inequality in the allocation of resources among parts of the organization.

Budgeting participation according to Wong-On-Wing et al [5] is a process of involvement of individual members of the organization in preparing the budget and has an influence on the preparation of budget targets used to evaluate performance.

\section{Managerial Performance}

Performance according to Mahoney [18] is related to management performance and based on management functions [5]. Managerial performance is defined by Mahoney [18] as the work of individual members of the organization in managerial activities such as planning, investigating, coordinating, supervising, staffing, negotiating and representing. Management performance is developed in functional classification which is directly related to management objectives. Robbins \& Judge [19] further define performance as a function of the outcome of the interaction between ability and motivation. The purpose and objectives of performance according to Simamora \& Ukar [20] are setting useful goals, not only for evaluating performance at the end of a certain period, but the results of work processes throughout that period. Mahoney [18] argues that functional classification in management performance is managerial skills and abilities, which can be determined based on performance measures in managerial activities. Performance will improve if superiors use the budget to allocate resources, because superiors can allocate more resources to more productive subordinates [21].

\section{Hypothesis Development}

Some literature has discussed the relationship between 
organizational commitment variables apparently affecting managerial performance. The results of the previous study were supported by Wong-On-Wing et al [5] showing the results that there is a positive relationship between budgetary participation and managerial performance, both directly and indirectly. One independent variable of research conducted by Hariyanti \& Purnamasari [3] pluriform motivation. Results of research by Hariyanti \& Purnamasari [3] show that there is a positive relationship between pluriform motivation on managerial performance. Research conducted by Nevita et al [22] and Basuki [23] also showed significant results. The hypothesis of this study is as following:

H1: There is a positive influence between budgetary participation on managerial performance.

H2: There is a positive influence between pluriform motivation on managerial performance

\section{Research Method}

\section{Research Design}

This study uses a research design with an explanatory method that is research activities that are based on a theoretical framework that describes the research problem with the expression of why and how the relationship of research variables. The study uses an analysis unit of managers working in manufacturing companies in Indonesia to analyze the effect of budget participation to managerial performance with the moderating effect of pluriform motivation (Figure 1).

\section{Definition of Variable Operations}

This study uses the independent variable budgetary participation and the dependent variable managerial performance and pluriform motivation as a moderating variable. Pluriform motivation is defined as motivation or encouragement that comes from within the individual and from external parties that make the individual do activity [3]. In this study, pluriform motivation was measured by intrinsic and extrinsic motivation indicators. Budget participation is defined as the involvement of organizational members in the budgeting process in their work units [3]. Managerial performance is defined as the performance of individual members of the organization in managerial activities, including the level of managerial skills in carrying out management activities which include some indicators of planning, coordinating, investigating, managing, negotiating, monitoring, and evaluating [5].

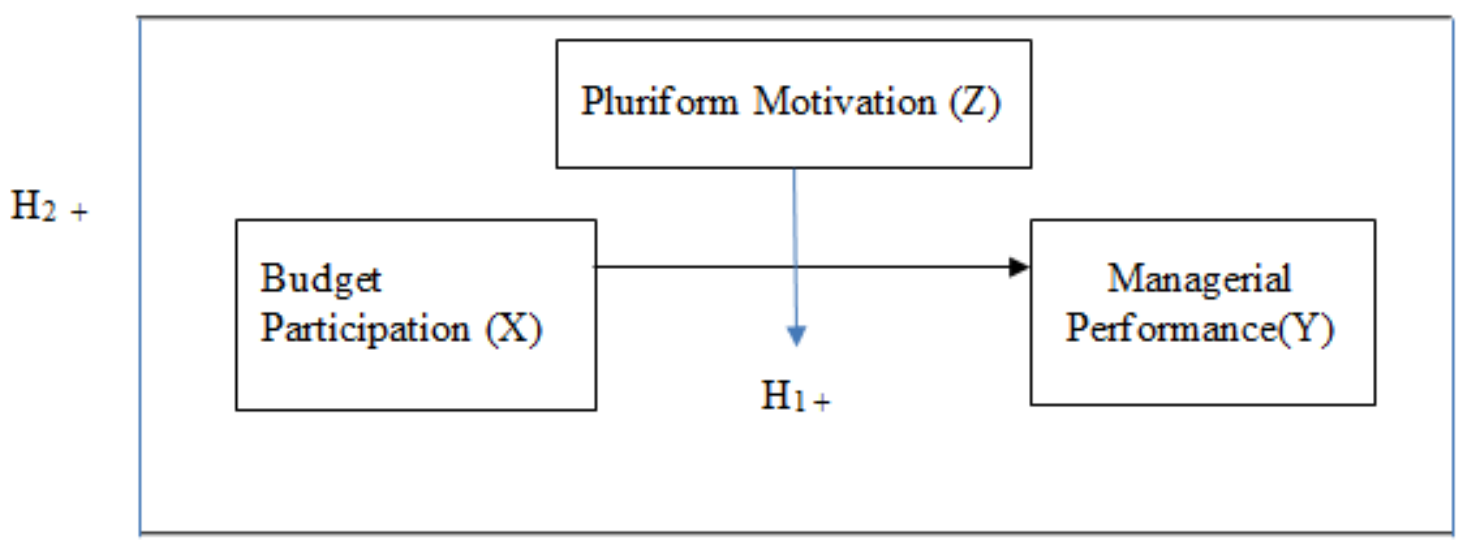

Figure 1. Research Model 


\section{Data Processing and Analysis Techniques}

Data collection was done through the mail survey method with data analysis conducted being in the form of descriptive analysis and inferential analysis. Descriptive analysis is used to find a general description of the respondent, including the level of education, gender and age of the respondent. Inferential analysis is performed using multiple regression analysis techniques.

Multiple regression analysis is used to determine the shape of the relationship between variables. The main purpose in using the analysis is to predict or estimate the value of a dependent variable in relation to the independent variable. The main purpose in using the analysis is to predict or estimate the value of a dependent variable in relation to the independent variable. Then the multiple regression model for the relationship of these variables can be stated with the following equation:

$$
\mathrm{MP}=\mathrm{a}+\mathrm{b}_{1} \mathrm{PM}+\mathrm{b}_{2} \mathrm{PM} \cdot \mathrm{BP}+\mathrm{e}
$$

Information:

$\mathrm{PM}=$ Pluriform Motivation; $\mathrm{BP}=$ Budget Participation; MP = Managerial Performance

The magnitude of the constant is reflected in "a", and the magnitude of the regression coefficients of each independent variable is indicated by $b_{1}$, and $b_{2}$. Testing of each proposed hypothesis can be done using the Significance test (real effect) of the independent variable $(\mathrm{X})$ on the dependent variable $(\mathrm{Y})$ with a statistical test $\mathrm{t}$ (t-test) and F test (F-test) at the level of $5 \%(\alpha=0.05$. Before the data is further processed, it needs to be tested for validity and reliability. The use of regression models must avoid the possibility of deviations from classical assumptions, so the classic assumption test is needed. Testing the hypothesis of this study uses MRA (Moderated Regression Analysis).

\section{Results and Discussion}

The study uses an analysis unit of managers who work in manufacturing companies in Indonesia. As for a brief overview, Indonesia has become the largest manufacturing industry base in ASEAN, contributing $20.27 \%$ to the national economy. The development of the manufacturing industry in Indonesia is currently able to shift the role of commodity based to manufacture based. The government is trying to transform the economy so that it is more focused on the process of developing the non-oil and gas industry. The manufacturing industry in Indonesia is considered to be more productive and can have a broad chain effect so as to increase the added value of raw materials, increase the workforce, generate the largest source of foreign exchange, and the largest tax and customs contributor. Several manufacturing sectors have a performance percentage above national GDP, including the base metal industry by $9.94 \%$, the textile and apparel industry by $7.53 \%$, and the transportation equipment industry by $6.33 \%$. Compared with neighboring countries in ASEAN which are more export-oriented, manufacturing in Indonesia has its strength in the domestic market with a percentage of $80 \%$ and the rest is the export market. Manufacturing Value Added (MVA) for the Indonesian manufacturing industry is in the top position among ASEAN countries with an achievement of $4.5 \%$. Meanwhile, globally, Indonesian manufacturing is ranked 9th out of all countries in the world.[24]

For this study, because the number of managers in each manufacturing company in Indonesia is unknown, the sample selection in this study uses a purposive sampling method, where the sample chosen from the population is determined based on research criteria. The method was chosen because the sample of this study was respondents with criteria occupying the position of manager for a minimum of 2 years. Based on the sample method used 500 questionnaires were sent to managers working in manufacturing companies in Indonesia. The total questionnaires returned were 140 , and there were 8 questionnaires whose filling was incomplete, and 10 questionnaires did not meet the research criteria so that the total number of questionnaires that could be processed was only 122 data.

Pluriform motivation was measured using nine instruments developed by Hariyanti \& Purnamasari [3]. Budget participation is measured using five instruments developed by Milani [13] in Wong-On-Wing et al [5]. Managerial performance is measured using the nine instruments developed by Mahoney [18]. The research instruments were measured using a seven point Likert scale.

Data analysis was performed multiple regression analysis. Before analysis, furthermore, the quality of the research data was tested with the validity and reliability tests. Based on the validity test shows that the calculated value of each item questionnaire statement is greater than $r$ table of 0.415 with $\mathrm{N}=122$ and $\alpha=0.05$ which means all items of the questionnaire statement for the variable organizational commitment, pluriform motivation, budget participation and managerial performance are valid [25]. The results of the validity tests of each instrument are presented in Table 1. 
Table 1. Validity Test Results

\begin{tabular}{|c|c|c|c|}
\hline Variable & r-stat. & r-table & Information \\
\hline X1 (PM) & 0.734 & 0.415 & Valid \\
\hline X2 (PM) & 0.785 & 0.415 & Valid \\
\hline X3 (PM) & 0.779 & 0.415 & Valid \\
\hline X4 (PM) & 0.729 & 0.415 & Valid \\
\hline X5 (PM) & 0.778 & 0.415 & Valid \\
\hline X6 (PM) & 0.752 & 0.415 & Valid \\
\hline X7 (PM) & 0.747 & 0.415 & Valid \\
\hline X8 (PM) & 0.782 & 0.415 & Valid \\
\hline X9 (PM) & 0.606 & 0.415 & Valid \\
\hline X10 (BP) & 0.649 & 0.415 & Valid \\
\hline X11 (BP) & 0.626 & 0.415 & Valid \\
\hline X12 (BP) & 0.653 & 0.415 & Valid \\
\hline X13 (BP) & 0.611 & 0.415 & Valid \\
\hline X14 (BP) & 0.653 & 0.415 & Valid \\
\hline Y1 (MP) & 0.623 & 0.415 & Valid \\
\hline Y2 (MP) & 0.645 & 0.415 & Valid \\
\hline Y3 (MP) & 0.658 & 0.415 & Valid \\
\hline Y4 (MP) & 0.674 & 0.415 & Valid \\
\hline Y5 (MP) & 0.640 & 0.415 & Valid \\
\hline Y6 (MP) & 0.659 & 0.415 & Valid \\
\hline Y7 (MP) & 0.677 & 0.415 & Valid \\
\hline Y8 (MP) & 0.605 & 0.415 & Valid \\
\hline Y9 (MP) & 0.682 & 0.415 & Valid \\
\hline
\end{tabular}

Source: Primary data processed in 2019

The reliability test is used to test the reliability of the measuring instrument or in other words to measure the consistency and stability of the instrument. The reliability test results of each instrument in the research variables are presented in Table 2.

Table 2. Reliability Test Results

\begin{tabular}{|c|c|c|c|}
\hline Variable & r-stat. & $\begin{array}{c}\text { Cronbach } \\
\text { Alpha }\end{array}$ & Information \\
\hline $\begin{array}{c}\text { Pluriform Motivation } \\
\text { (PM) }\end{array}$ & 0.7860 & 0.6000 & Reliable \\
\hline $\begin{array}{c}\text { Budget Participation } \\
\text { (BP) }\end{array}$ & 0.8150 & 0.6000 & Reliable \\
\hline $\begin{array}{c}\text { Managerial } \\
\text { Performance (MP) }\end{array}$ & 0.8290 & 0.6000 & Reliable \\
\hline
\end{tabular}

Source: Primary data processed in 2019

From table 2, $\mathrm{r}_{\text {stat. }}$ from Cronbach-alpha is greater than the correlation coefficient above 0.60 . It can be concluded that the three variables namely pluriform motivation, budgetary participation and managerial performance are reliable or reliable.

This study uses MRA analysis techniques, therefore it is necessary to test the classical assumptions. Data normality testing is done by looking at the probability plot that compares the cumulative distribution with the normal distribution. If the residual data distribution is normal, then the line that describes the actual data will follow the diagonal line [25]. The normality test results are shown in Figure 2.

\section{Normal P-P Plot of Regression Standardized Residual}

Dependent Variable: Kinerja Manajerial

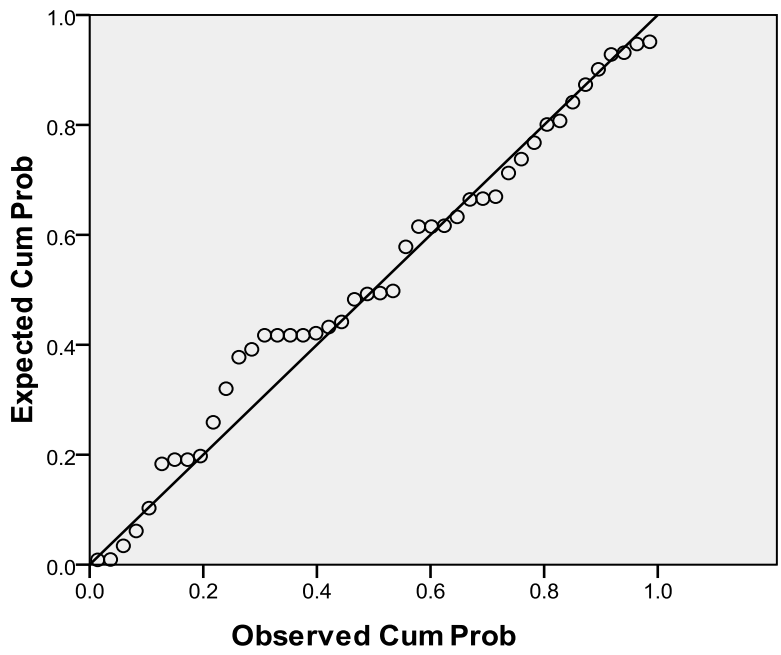

Source: Primary data processed in 2019

Figure 2. Normality Test Results with Scatter Plot Diagram

Testing the symptoms of multicollinearity between independent variables uses the variance inflation factor (VIF). The results show the amount of VIF of each independent variable can be seen in Table 3 .

Table 3. VIF Calculation Results

\begin{tabular}{|c|c|c|c|}
\hline \multicolumn{2}{|c|}{ Model } & Tolerance & VIF \\
\hline 1 & Pluriform Motivation (PM) & .504 & 2.878 \\
\hline & Budget Participation (BP) & .684 & 1.961 \\
\hline
\end{tabular}

Source: Primary data processed in 2019

Table 3 shows that budget participation and pluriform motivation variables do not occur multicollinearity because the VIF value $<5.00$. Thus pluriform motivation and budgetary participation variables can be used in research as factors that affect managerial performance. This study uses the Glejser Test to detect the presence or absence of heteroscedasticity. The test results are shown in Table 4.

Table 4. Heteroscedasticity Test Results

\begin{tabular}{|c|c|c|c|c|c|c|}
\hline \multicolumn{2}{|c|}{ Model } & B & $\begin{array}{c}\text { Std. } \\
\text { Error }\end{array}$ & Beta & t & Sig \\
\hline 1 & (Constant) & $-2.008 \mathrm{E}-15$ & 6.064 & & .000 & 1.000 \\
\hline & PM & .000 & .223 & .000 & .000 & 1.000 \\
\hline & BP & .000 & .135 & .000 & .000 & 1.000 \\
\hline
\end{tabular}

Source: Primary data processed in 2019 
Based on the results shown in table 4, it appears that all independent variables show insignificant results, so it can be concluded that the independent variables do not occur heteroscedasticity in the error variant. Moderated Regression Analysis is used in this study to determine the effect of budgetary participation variables on managerial performance variables and the effect of budgetary participation on managerial performance with pluriform motivation moderation.

Table 5. Results of Moderated Regression Analysis

\begin{tabular}{|c|c|c|c|}
\hline Variable & Regression Coef & t-stat. & Sig. \\
\hline Constanta & -11.837 & -2.357 & 0.018 \\
\hline BP & 0.783 & 5.136 & 0.000 \\
\hline BP.PM & 0.712 & 4.078 & 0.001 \\
\hline
\end{tabular}

Source: Primary data processed in 2019

Based on the results of the regression analysis in table 5, the multiple linear regression equation is obtained as follows:

$$
\mathrm{Y}=-11.837+0.783 \mathrm{X}_{1}+0.712 \mathrm{X}_{2} \cdot \mathrm{X}_{3}+\mathrm{e}
$$

The interpretation of the multiple regression equation above shows that each regression coefficient is positive, the results indicate that increasing budgetary participation and pluriform interaction of motivation with budgetary participation will improve managerial performance. The results of data processing and discussion of the results of hypothesis testing are used to determine whether there is an influence between each independent variable on the dependent variable. The results of the analysis obtained the value of $t$ presented in Table 6 .

Based on the results of the analysis in table 6, it can be explained that: (1) Variable budgetary participation has a significant positive effect on managerial performance. These results are supported by previous research conducted by Wong-On-Wing et al., [4] and Hariyanti \& Purnamasari [2] that budgetary participation influences managerial performance improvement. In addition, the results of this study were also supported by research by Owusu et al [8] which directly tested the relationship of budgeting participation to managerial performance which showed a positive relationship. (2) The results of interaction between budgetary participation variables and pluriform motivation show a probability value of $0.001<\alpha$ (0.05) which means that pluriform motivation is moderation. The results of the study explain that pluriform motivation moderates budgetary participation on positive managerial performance, so it can be said that pluriform motivation strengthens the relationship. This is also in line with previous research [26, 27, 28] highlighting the importance of budgeting and financial performance and standards in manufacturing companies.

Tests to determine the feasibility of the research model in this study using the $\mathrm{F}$ test. The results of the analysis using the F Test are shown in Table 7.

The results of data analysis and calculations obtained an $F$ value of 73.127 and a significance value of 0.000 . Because the significance value is less than $5 \%$, it can be explained that the model in this study is feasible and acceptable. The coefficient of determination (R2) essentially measures how far the model's ability to explain the variation of the dependent variable. A value close to one means that the independent variables provide almost all the information needed to predict variations in the dependent variable [25]. The results of the analysis using the coefficient of determination can be seen in Table 8 .

The coefficient of determination (adjusted R2) of 0.614 or when used as a percentage produces a value of $61.40 \%$ this means that $61.40 \%$ variation in managerial performance can be explained by variations in budgetary participation.

Table 6. Hypothesis Testing Results

\begin{tabular}{|c|c|c|c|c|c|c|}
\hline Variable & $\mathbf{t}_{\text {Count }}$ & Sign & $\mathbf{t}_{\text {table }}$ & $\mathbf{B}$ & Conclusion & Information \\
\hline BP & 5,136 & 0.001 & 2,021 & 0.752 & Significant & Accepted \\
\hline BP.PM & 4,078 & 0.000 & 2,021 & 0.684 & Significant & Accepted \\
\hline
\end{tabular}

Source: Primary data processed in 2019

Table 7. Test F Calculation Results

\begin{tabular}{|c|c|c|c|c|c|c|}
\hline \multicolumn{2}{|c|}{ Model } & Sum of Squares & Df & Mean Square & F & Sig. \\
\hline \multirow{2}{*}{1} & Regression & 684.128 & 3 & 189.723 & 73.127 & $.000^{\mathrm{a}}$ \\
\cline { 2 - 7 } & Residual & 101.491 & 120 & 2.637 & & \\
\cline { 2 - 7 } & Total & 785.619 & 122 & & & \\
& & & & & \\
\end{tabular}

Source: Primary data processed in 2019

Table 8. Results of the Determination Coefficient Analysis

\begin{tabular}{|c|c|c|c|c|c|}
\hline Model & $\mathbf{R}$ & R Square & Adjusted R Square & Std. Error of the Estimate & Durbin-Watson \\
\hline 1 & $.823^{\mathrm{a}}$ & .614 & .678 & 1.398 & 2.138 \\
\hline
\end{tabular}

Source: Primary data processed in 2019 


\section{Conclusions}

Based on the results of the data analysis and discussion above, it can be concluded that organizational commitment, pluriform motivation and budgetary participation positively influence managerial performance. This is based on the results of the regression equation, namely: $\mathrm{Y}=-11,837+0.783 \mathrm{X}_{1}+0.712 \mathrm{X}_{2} \mathrm{X}_{3}+\mathrm{e}$ and these results indicate that the regression coefficient for each independent variable is positive.

The $t$ test results showed that the independent variable of budget participation had a positive and significant effect on managerial performance. Based on the results of the $\mathrm{F}$ test, it can be concluded that the model in this study is feasible. Based on moderated regression analysis the results show that pluriform positive motivation is significant as a moderating variable in the relationship of budgetary participation to managerial performance. The results also showed that the independent variable of budgetary participation and moderating variables namely pluriform motivation influenced managerial performance variation which was relatively high at $61.40 \%$.

Based on the results of the research, the management of manufacturing companies in Indonesia need to make policies that support the existence of budgetary participation by employees in the budget preparation process in each work unit. The management also needs to pay attention that there is intrinsic motivation, autonomous and controlled extrinsic motivation which can motivate employees to excel and improve their performance. In addition, it is necessary to conduct coaching and persuasive approaches to all members of the organization to maintain and improve their achievements and performance so that the company also improves its performance. The results of this study can be used as a reference for conducting research by developing research literature in the same field. The limitation of this study is that the results of the study cannot be generalized, because this study only uses research objects in manufacturing companies in Indonesia.

\section{REFERENCES}

[1] Deci, E. L., Ryan, R. M. The "what" and "why" of goal pursuits: Human needs and the self-determination of behavior. Psychological inquiry. 2000 Oct 1;11(4):227-68.

[2] Anthony, R. N., Govindarajan, V., \& Dearden, J. Management control systems (Vol. 12). New York: McGraw-Hill; 2007.

[3] Hariyanti, W., Purnamasari P. Pluriform motivation as antecedent and its relationships to budgeting participation and managerial performance (Empirical Study on Manufacturing Companies listed on Indonesian Stock Exchange). Procedia-Social and Behavioral Sciences. 2015 Nov 25;211:836-43.
[4] Wang, C. L., Indridason, T., \& Saunders, M. N. Affective and continuance commitment in public private partnership. Employee Relations. 2010; 32(4):396-417

[5] Wong-On-Wing, B., Guo L, Lui G. Intrinsic and extrinsic motivation and participation in budgeting: Antecedents and consequences. Behavioral Research in Accounting. 2010;22(2):133-153.

[6] Locke, E. A., \& Latham, G. P.. Goal setting theory. In H. F. O'Neil, Jr. \& M. Drillings (Eds.), Motivation: Theory and research (pp. 13-29). Hillsdale, NJ: Lawrence Erlbaum; 1994.

[7] Macey, W.H., Schneider, B. The meaning of employee engagement. Industrial and organizational Psychology. 2008 Mar;1(1):3-30.

[8] Mohhamad, M., Sulistiyowati, F., Purwanugraha, H.A. Akuntansi Sektor Publik (public sectors accounting). Penerbit BPFE. Yogyakarta. 2013.

[9] Owusu, E. E., Dwomoh, G., Collins, M., Yaa, G., Daniel, O. Assessing the Relationship between the Budget Participation and Employees' Performance of Public Universities in Ghana: a Case of the University of Education. International Journal of Academic Research in Accounting, Finance and Management Sciences. 2014 Jan;4(1):85-96.

[10] Chong, V. K., Chong, K. M. Budget goal commitment and informational effects of budget participation on performance: A structural equation modeling approach. Behavioral Research in Accounting. 2002;14(1):65-86.

[11] Gagné, M., Deci, E. L. Self - determination theory and work motivation. Journal of Organizational behavior. 2005 Jun;26(4):331-62.

[12] Brownell, P., Hirst, M. Reliance on accounting information, budgetary participation, and task uncertainty: tests of a three-way interaction. Journal of accounting Research. 1986 Oct 1:241-9.

[13] Milani, K. The relationship of participation in budget-setting to industrial supervisor performance and attitudes: a field study. The accounting review. 1975 Apr 1;50(2):274-84.

[14] Tremblay, M., Blanchard, C., Taylor, S., Pelletier, L., Villeneuve, M. Work Extrinsic and Intrinsic Motivation Scale: Its Value for Organizational Psychology Research. Canadian Journal of Behavioural Science/revue canadienne des sciences du comportement. 2009 Oct;41(4):213-226.

[15] Vansteenkiste, M., Lens, W., Deci, E. L. Intrinsic versus extrinsic goal contents in self-determination theory: Another look at the quality of academic motivation. Educational psychologist. 2006 Mar 1;41(1):19-31.

[16] Mardiasmo, D. Akuntansi Sektor Publik. Yogyakarta: ANDI. 2009.

[17] Siegel, G. Ramanauskas-Marconi H. Behavioral accounting. Ohio: Thomson South-Western; 1989.

[18] Mahoney, T. A. Development of managerial performance: A research approach. Ohio: South-western Publishing Company; 1963.

[19] Robbins, S. P. \& Judge, T. A. Organizational Behavior, $15^{\text {th }}$ ed. Pearson Education, Boston, MA: 2013. 
[20] Simamora, M., Ukar, K. Small and Medium Enterprises (SMEs) and Technology Incubation Program in Indonesia-Current Issues and Challenges. Available at SSRN 2729085. 2007 Jul 2.

[21] Fisher, J., Frederickson, J. R., Peffer, S. A. The effect of information asymmetry on negotiated budgets: An empirical investigation. Accounting, Organizations and Society. 2002 Jan 1;27(1-2):27-43.

[22] Nevita, A. O., Imaningati, S., \& Farida, D. N. Pengaruh Partisipasi Anggaran terhadap Kinerja Manajerial dengan Pengetahuan manajemen Biaya dan Budaya Organisasi sebagai Variabel Pemoderasi. PRESTASI. 2014; 13(1); 71-81.

[23] Basuki, B. Eco-Efficiency and sustainable development as efforts to produce environmentally friendly product: An exploratory case study. Issues In Social And Environmental Accounting. 2015; 9(3):199-218.
[24] Indonesia Investment Coordinating Board. (2017). Industri Manufaktur di Indonesia Sebagai Basis Produksi di ASEAN. Retrieved from https://www.investindonesia.go.id/id/artikel -investasi/detail/perkembangan-industri-manufaktur-di-indo nesia

[25] Ghozali, I. Aplikasi analisis multivariate dengan program SPSS. Semarang: Universitas Diponegoro Press; 2006.

[26] Hoshino, Y. Effect of IFRS Adoption on Corporate Performance Measurement: Analysis of Japanese Manufacturing Companies. Universal Journal of Accounting and Finance. 2017;5(4), 78 - 90.

[27] Deyganto, K. O., \& Alemu, A. A. (2019). Factors Affecting Financial Performance of Insurance Companies Operating in Hawassa City Administration, Ethiopia. Universal Journal of Accounting and Finance (1), 1-10.

[28] Shittu, W. (2019). Self-Control and Social Development: Evidence from Kenya. Arthatama, 3(2), 83-99. 